\title{
トライボコーティング法による真空用玉軸受の摩擦制御
}

\author{
足立 幸志 $* 1 \cdot$ 鈴木 論道 $* 2 \cdot$ 渋谷 裕行*3 \\ 加藤 康司*4 . 小原 新吾 $* 5$
}

\section{Tribo-coatings for Friction Control of Ball Bearings in Ultra High Vacuum}

\author{
Koshi ADACH*1, Rondo SUZUKI*2, Hiroyuki SHIBUYA*3, \\ Koji KATO*4 and Shingo OBARA*5
${ }^{* 1}$ School of Mechanical Engineering, Tohoku University Aramaki-aza-aoba 6-6-01, Aoba-ku, 980-8579 Sendai *2Tokyo Electric Power Company, Futaba-gun, 979-0402 Fukushima
${ }^{* 3}$ NS Solutions Corporation, Chuo-ku, 104-0033 Tokyo
${ }^{*}$ Nihon University, 963-8642 Koriyama \\ *5Japan Aerospace Exploration Agency, Sengen, 305-8505 Tsukuba
}

(Received February 15, 2008, Accepted May 10, 2008)

\begin{abstract}
Lubrication is one of the most important key technologies for reliable and durable machines in ultra high vacuum. Solid lubricants, which are pre-coated before operation by a certain amount thickness, are commonly used for the system. The life of present system is, therefore, determined by the wear life of the coating of lubricant.

To extend its lifetime, a new lubrication method for in-situ and on-demand restoration of the lubricants called as "Tribo-coating" had been introduced, and its effectiveness as practical solid lubrication method for sliding element has been clearly shown.

This paper introduces the unique advantage of excellent tribological performance of tribo-coating film for ball bearings, and the usefulness of the tribo-coating for friction control of ball bearings in ultra high vacuum is clearly shown.
\end{abstract}

\section{1. 緒訔}

宇宙機器に代表される真空環境下における機械機器のしゅ う動部の多くは, 高い飽和蒸気圧, 優れた保存性と清浄性の 観点から金 $(\mathrm{Au})$, 銀 $(\mathrm{Ag})$, 鉛 $(\mathrm{Pb})$, 二硫化モリブデン $\left(\mathrm{MoS}_{2}\right)$ 等の固体潤滑膜により潤滑される1-3). しかし固体 潤滑は，液体を用いた潤滑と比較し「高摩擦」であり，いず れも事前に被覆した一定厚さの被膜の摩耗による「寿命」が 存在するなどの本質的に避けられない欠点を有している

これに対し，従来使用されている軟質金属薄膜より低い摩 擦係数を半永久的に持続することのできる固体潤滑法として $\lceil$ In-situ トライボコーティング潤滑法（摩擦支援型蒸着法）」 が提案され7), すべり摩擦試験においてその有効性が実証さ れている7-10).

本論文では，インジウムのトライボコーティングを施した 玉軸受の摩擦特性に及ぼす軸受構造とトライボコーティング 条件の影響を明らかにし，トライボコーティングにより 0.005 以下の安定した低い摩擦係数を得るための必要条件を 明らかにする，さらに，それらの結果にもとづき真空用玉軸 受に対するトライボコーティング法の有効性を明らかにす る.

*1 東北大学大学院工学研究科（干980-8579 仙台市青葉区荒巻字 青葉 6-6-01)

*2 東京電力秼) ( $9979-0402$ 福島県双葉郡広野町下北迫二ツ沼58)

*3 新日鉄ソリューションズ怢（テ104-0033 東京都中央区新川 220-15)

*4 日本大学（干963-8642 郡山市田村町徳定字中河原 1)

*5 宇宙航空研究開発機構（干305-8505 茨城県つくば市千現 2-11)

\section{2. 実験装置及び実験方法}

2.1 実験装置：玉軸受のためのトライボコーティング システム

トライボコーティング法とは, 摩擦支援下で真空蒸着を行 なう成膜法である ${ }^{7-10)}$. 真空蒸着中に摩擦を負荷することに より母材との付着力の強い優れた潤滑性を有する被膜が形成 されるところに最大の特徵がある. 真空蒸着システムを有す る玉軸受摩擦試験機（玉軸受のトライボコーティングシステ ム）の概略を Fig. 1 に示す．スラスト荷重は錘によって外 輪のみに与られ, 軸受の内輪はモータにより駆動される. 軸 受に発生する摩擦力は外輪の回転を抑える板ばねに貼り付け たひずみゲージの出力から算出される，潤滑剤（インジウ ム：In）を内蔵しモリブデン（Mo）線を巻きつけたアルミ ナ製の坩堝が玉軸受の下部に設置され，モリブデン線に通電 加熱することより摩擦中に任意のタイミングで潤滑材料を蒸 発させ，玉軸受にトライボコーティング膜を形成させること が可能である。これらの装置は， $10^{-6} \mathrm{~Pa} の$ 真空下に設置さ れ実験が行なわれる.

\section{2 試験片}

本実験には, 保持器の有無及び球の材質を变化させた 3 種類の深溝玉軸受を使用した. 内外輪はすべて SUS440Cで あり保持器は SUS304, 球は窒化ケイ素 $\left(\mathrm{Si}_{3} \mathrm{~N}_{4}\right)$ 及び SUS440Cの 2 種類を用いた. また摩擦特性の相対比較のた め, 従来真空用玉軸受として使用されている PTFEの保持 器を有し $\mathrm{MoS}_{2}$ のスパッタリング膜を施した深溝玉軸受を用 いた.

\section{3 トライボコーティング膜の摩擦特性の評価}

インジウムのトライボコーティングが施された玉軸受 (球: $\mathrm{Si}_{3} \mathrm{~N}_{4}$, 内外輪 : $\mathrm{SUS} 440 \mathrm{C}$ ) の典型的な摩擦係数の変 


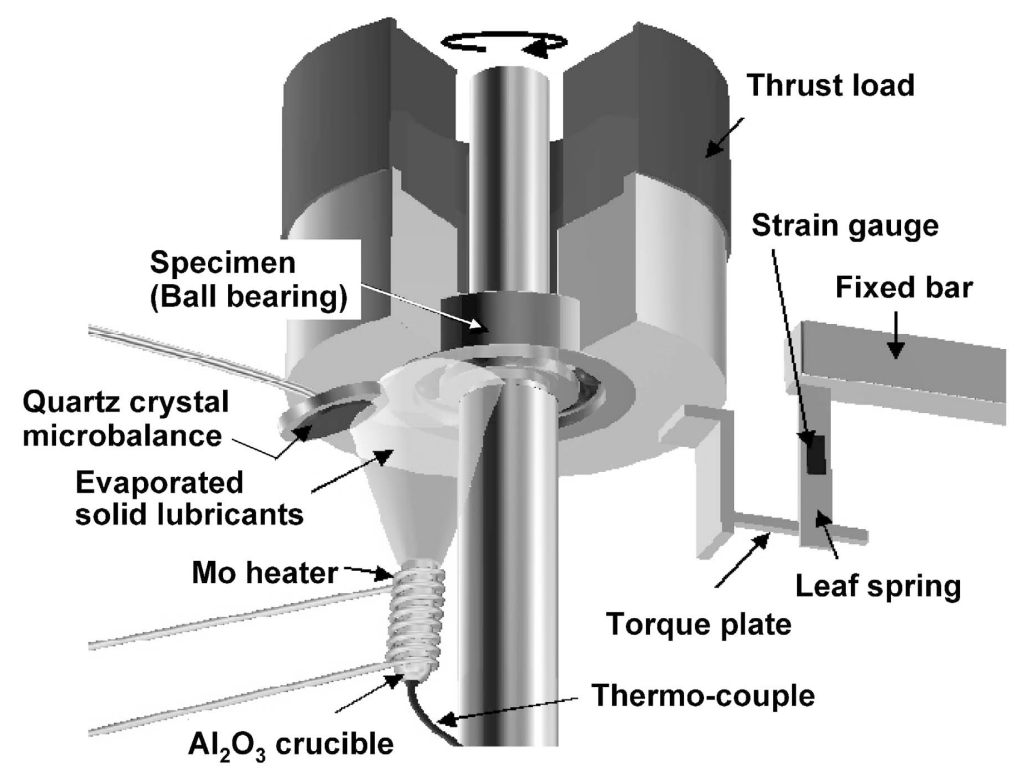

Fig. 1 Schematic illustration of friction apparatus for ball bearings with tribo-coating system.

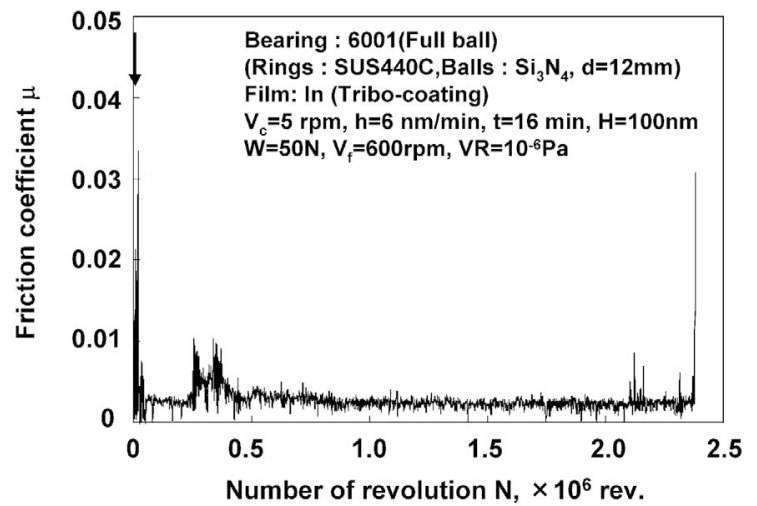

Fig. 2 Representative friction curve of ball bearing lubricated by tribo-coated In film.

化を Fig. 2 に示す．ここで図中に打ける矢印はトライボ コーティング膜形成のための蒸着のタイミングを示してい る. 摩擦係数は初期に急増するもののすぐに減少し安定した 低い值を示す。一定期間の安定した摩擦を示した後，摩擦係 数が急増する.この安定時の摩擦保数と摩擦係数が急増する までの期間によりトライボコーティングを施した玉軸受の摩 擦係数と寿命を評価した。

\section{3. 実験結果及び考察}

\section{1 再トライボコーティングによる潤滑性能の修復}

Fig. 2 に示すように 1 回の潤滑剤供給で形成されるトライ ボコーティング膜の寿命は有限である。この寿命に達した瞬 間に真空蒸着を再び行なった場合の摩擦特性を Fig. 3 に示 す。トライボコーティング膜の再形成により，上昇した摩擦 を再び低摩擦に修復することが可能であることが確認でき る.この結果は，再トライボイコーティングにより玉軸受の 低摩擦の修復が可能であり, 半永久の低摩擦の持続が原理的 に可能であることを示している.

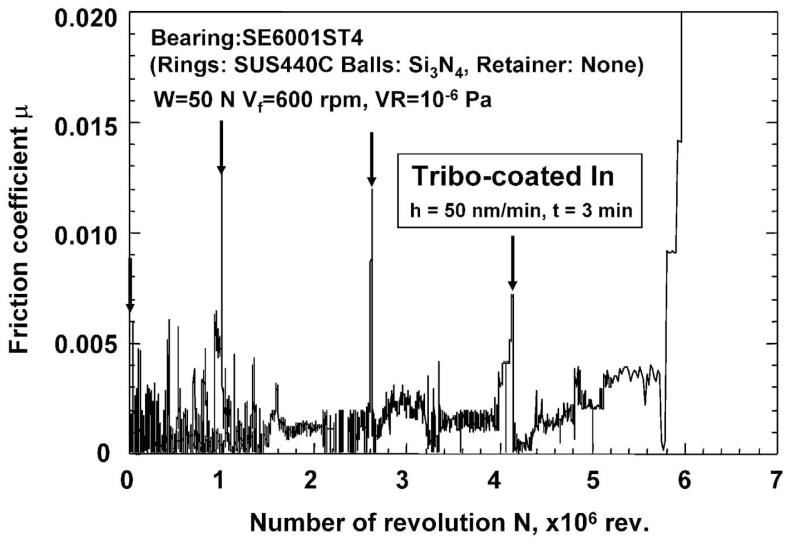

Fig. 3 In-situ and on-demand restoration of lubrication property of the ball bearing lubricated by tribo-coating.

\section{2 トライボコーティング膜の摩擦特性に及ぼす軸受 構造の影響}

Fig. 4 に保持器付玉軸受にインジウムのトライボコーテ ィングを施した時の摩擦特性に及ぼす球材質の影響を示す。 SUS440C 球を用いた場合には，摩擦係数の上昇時に焼付き が発生し，再トライボコーティングを施しても低摩擦は実現 しない，これに対し $\mathrm{Si}_{3} \mathrm{~N}_{4}$ 球を用いた場合には，定常状態に 打海摩擦係数も相対的に安定しており Fig. 3 に示すと扔 り再トライボコーティングにより上昇した摩擦を再び低減さ せ得ることが分かる．以上より耐燒付性に優れるセラミック $\left(\mathrm{Si}_{3} \mathrm{~N}_{4}\right)$ 球を有する玉軸受に扔いてトライボコーティング潤 滑法の有効性が発揮されるといえる.

この結果にもとづき以後すべての実験においては, $\mathrm{Si}_{3} \mathrm{~N}_{4}$ 球を有する玉軸受を使用した。

3.3 トライボコーティングを施した玉軸受の寿命に及ば す軸受構造と成膜条件の影響

Fig. 5 に 2 種類の蒸着速度でトライボコーティングを施 した玉軸受の摩擦特性を示す。また Fig. 6 に保持器の有無 


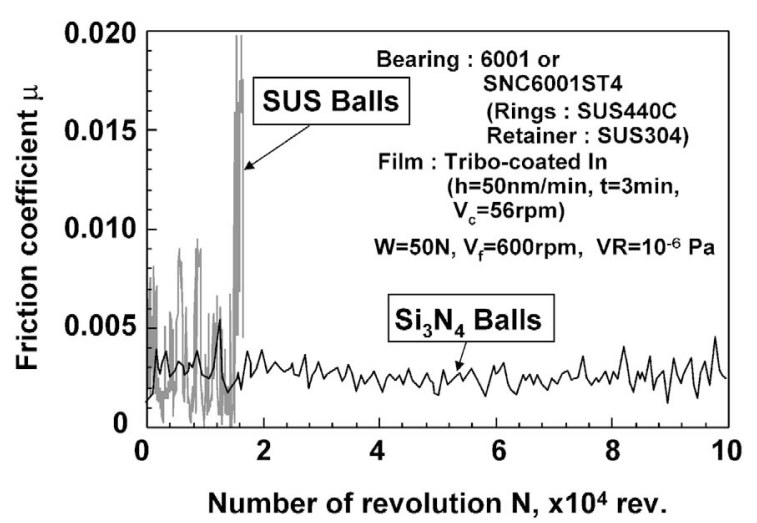

Fig. 4 Effect of ball material on friction properties of ball bearings lubricated by tribo-coated In film.

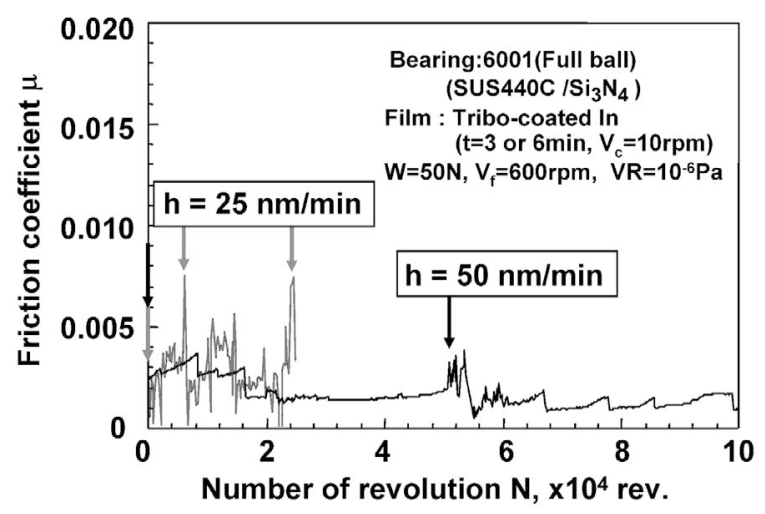

Fig. 5 Effect of coating speed on friction properties of ball bearings lubricated by tribo-coated In film.

の違いを有する 2 種類の玉軸受にトライボコーティングを 施した場合の寿命に及ぼす蒸着時の回転速度の影響を示す。

トライボコーティングを施した玉軸受の長寿命を実現するた めには, 高い蒸着速度と蒸着時の低い回転速度が有効である ことが分かる。これは, 摩擦面に扔いて球により摩擦が負荷 される前に摩擦面に供給される膜厚が厚いほど長い寿命を与 ええることに対応する．そこで, 内外輪のある 1 点におい て, 球と球が通過する間に供給される蒸着膜の膜厚 $h_{c}$ を $(1)$ 式で定義し， $h_{c}$ 値とトライボコーティングを施した玉軸受 の寿命の関係を Fig. 7 に示す.

$$
h_{c}=\frac{h}{V_{c} N}
$$

ここで, $h$ は蒸着速度, $V_{c}$ は蒸着時の回転速度, $N$ は玉軸 受の球の個数である.

Fig. 7より $h_{c}$ 值が0.3-0.4 nm 程度で急激に寿命が増加し， $0.4 \mathrm{~nm}$ 以上の場合に，トライボコーティングにより十分な 寿命が得られることが分かる. 即ち, $h_{c}$ 值 $>0.4 \mathrm{~nm}$ が低摩 擦を長期間持続するためのトライボコーティング膜形成のた めの一つの必要条件となる.ささに Fig. 6, Fig. 7 より保持 器付玉軸受と比較し保持器を有しない総玉軸受によって, よ り長い寿命を与えられることが分かる．即ちセラミックの総 玉軸受に扔いてトライボコーティング潤滑法の有効性が発揮 されるといえる.

この結果にもとづき以後の実験においては， $\mathrm{Si}_{3} \mathrm{~N}_{4}$ の総玉

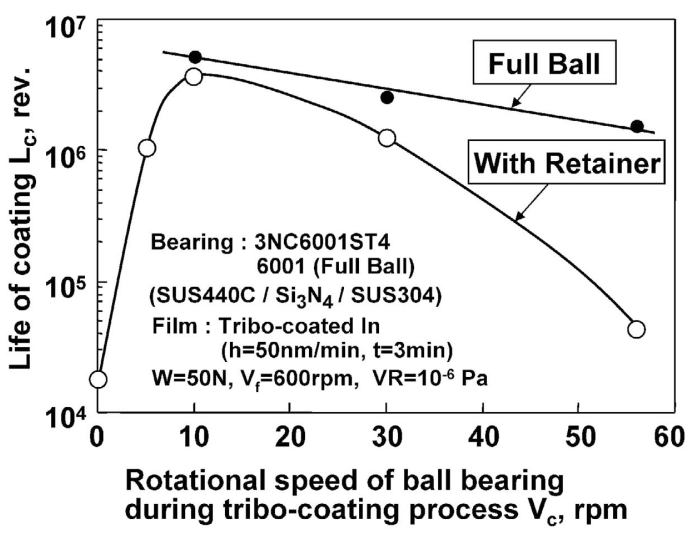

Fig. 6 Effect of rotational speed during tribo-coating process on life of tribo-coated In film.

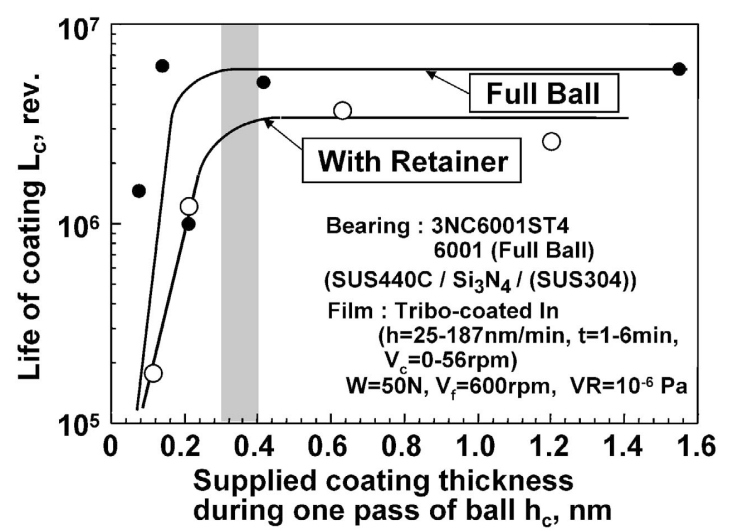

Fig. 7 Life of tribo-coated In film as a function of supplied coating thickness during one pass of the ball.

軸受を使用し， $h_{c}$ 值が $0.4 \mathrm{~nm}$ 以上となる条件で成膜を行な った.

\section{4 トライボコーティングを施した玉軸受の摩擦係数に 及ぼす成膜条件の影響}

3 種類のトライボコーティング時の供給膜厚における玉軸 受の摩擦特性及び 4 種類の荷重条件においてトライボコー ティングを施した玉軸受の摩擦特性を各々 Fig. 8, Fig. 9 に 示す.トライボコーティング時の供給膜厚及び荷重によって 玉軸受の摩擦特性は大きく変化することが分かる．0.005以 下の安定した低い摩擦係数, 0.01 以上の不安定な高い摩擦係 数及びそれら中間の摩擦挙動を示す荷重と供給膜厚条件を Fig. 10に示す.これはトライボコーティングにより安定し た低摩擦を得るための必要条件が, 最適な荷重と供給膜厚条 件として与えられることを示している.

\section{5 従来の真空用玉軸受との比較}

本実験条件範囲内に抢いて, 安定した低摩擦を与える最適 な成膜条件でトライボコーティングを施した $\mathrm{Si}_{3} \mathrm{~N}_{4}$ の総玉軸 受の摩擦特性と従来宇宙機器用玉軸受として用いられている $\mathrm{MoS}_{2}$ のスパッタリング膜を施した玉軸受の摩擦特性との比 較を Fig. 11に示す. 最適条件に扔いてトライボコーティン グを施すことにより, 従来の真空用玉軸受と同等以下の安定 した低い摩擦特性を与え得る玉軸受が実現可能であると結論 付けられる. 


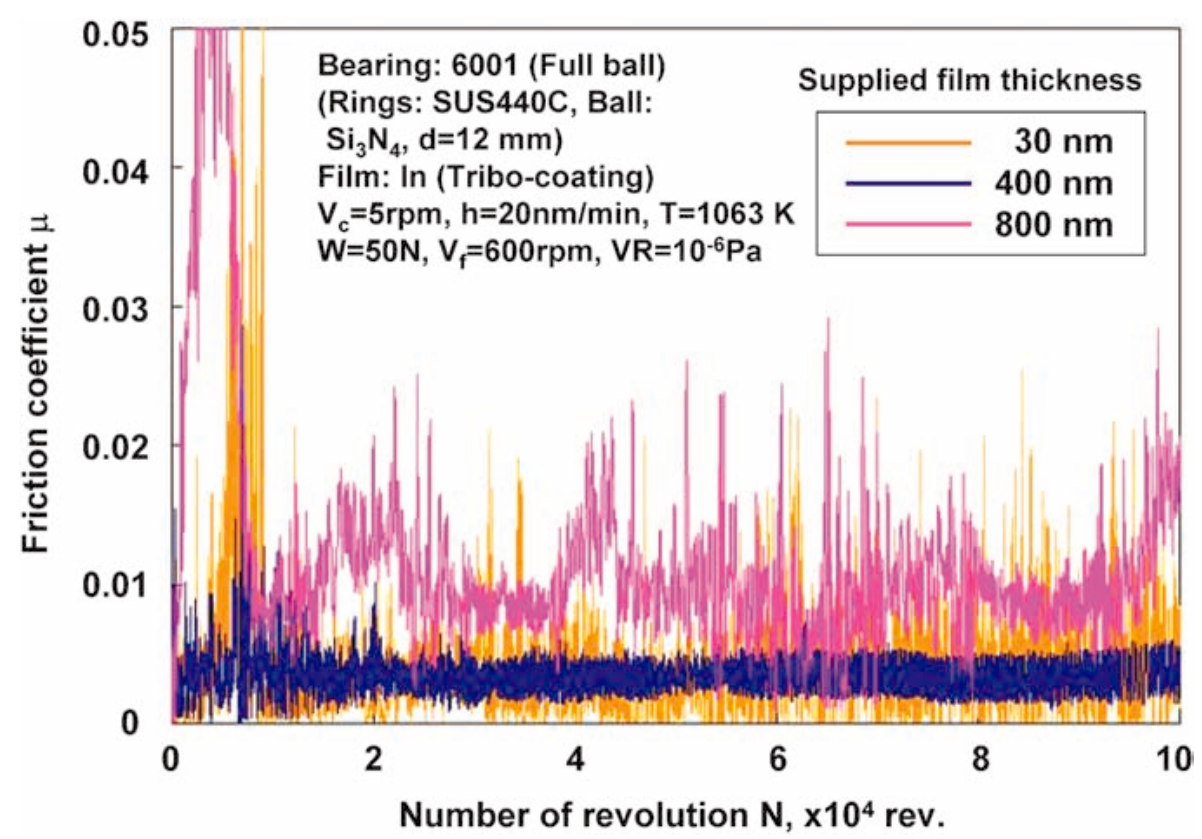

Fig. 8 Effect of supplied film thickness on friction properties of ball bearings lubricated by tribo-coated In film.

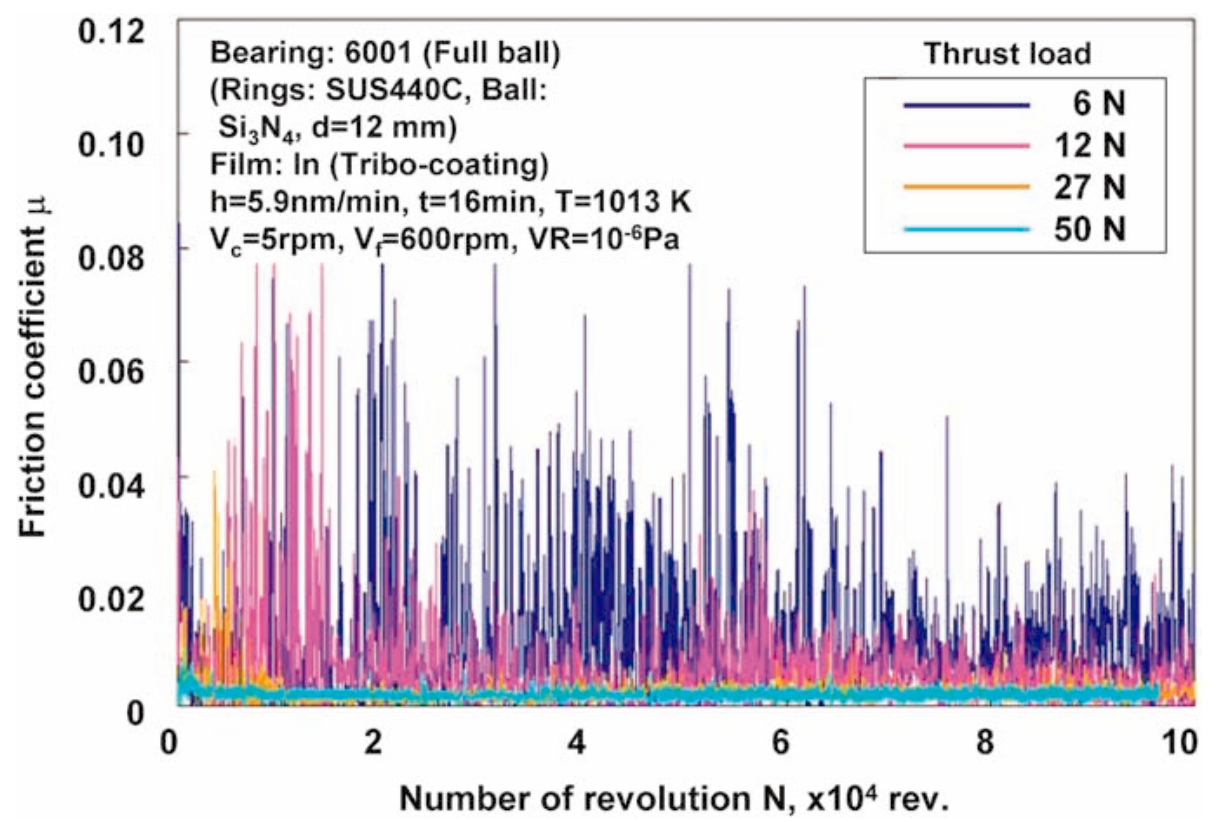

Fig. 9 Effect of thrust load on friction properties of ball bearings lubricated by tribo-coated In film.

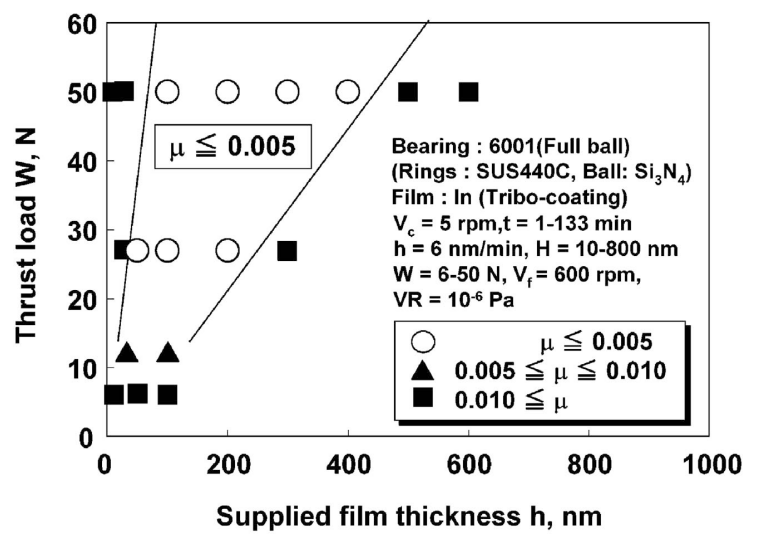

Fig. 10 Distribution of friction coefficients of the ball bearing after tribo-coating of In.

\section{6 玉軸受におけるトライボコーティング膜}

Fig. 12にインジウムのトライボコーティング膜を施した 玉軸受において安定した低摩擦が得られた時の玉軸受の球と 内輪の SEM 写真を示す. 球表面には摩擦によって形成され たと考えられる移着膜がほとんど観察されていないのに対し 内輪の転送面には，一様な移着膜が形成されていることがわ かる. 同様の一様な被膜は，外輪の転送面にも形成されてい ることが観察されている. トライボコーティングを施した玉 軸受では, トライボコーティングのための潤滑剤の蒸着は, 玉軸受の一部分に行なわれるものの, 玉軸受の回転に伴い潤 滑剤であるインジウムは, 玉を媒体に内外輪の転送面に一様 な膜を形成しこれが潤滑膜（トライボコーティング膜）とし て機能するといえる。 
Fig. 13に種々の成膜条件において観察された内輪転送面 上のトライボコーティング膜の典型的な 3 つの形態を示 す。供給膜厚が不十分である場合, 部分的な島状の膜が形成 され（Fig. 13(a)），供給膜厚が過㮃である場合膜が厚く形 成され (Fig. 13(c)) 膜の部分的な脱落が発生している事が わかる．これらに対し安定した低い摩擦係数が得られている 場合には, 均一な移着膜が形成される（Fig. 13(b)）ことが わかる. 即ち, Fig. 10に抏いて0.005以下の安定した低い摩
擦係数を実現する条件は, トライボコーティング形成過程に おいて内外輪に一様な膜を形成させ得る条件であるといえ る. また, このような均一なトライボコーティング膜は, 真 空中での摩擦に伴うなじみ過程と成膜過程が同時に行なわれ ることにより自己形成させるものであり, 下地との密着性の 高いことが期待される．これが，トライボコーティング法の 最大の特徴であるといえる.

トライボコーティング膜の低摩擦発生機構, 低摩擦を発生

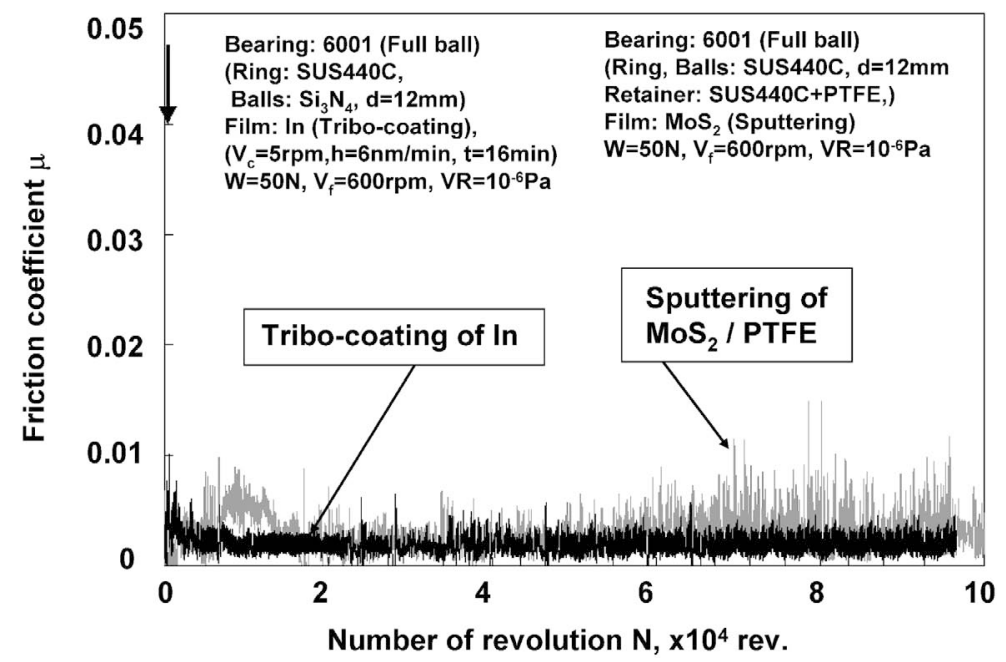

Fig. 11 Friction properties of ball bearings lubricated by tribo-coating film and conventional solid lubricant.

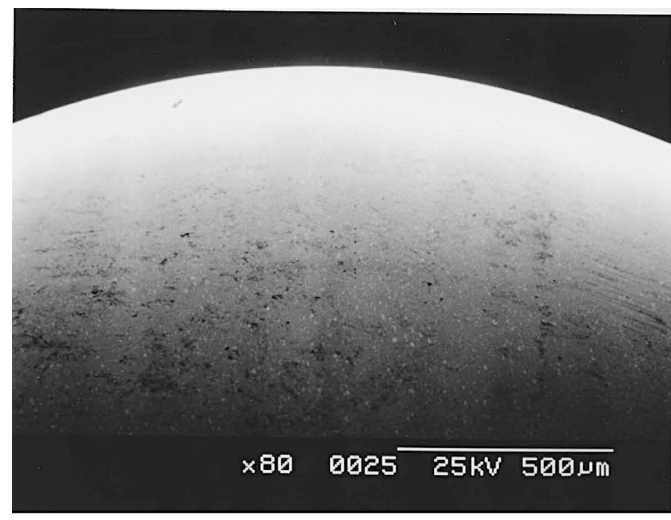

(a)

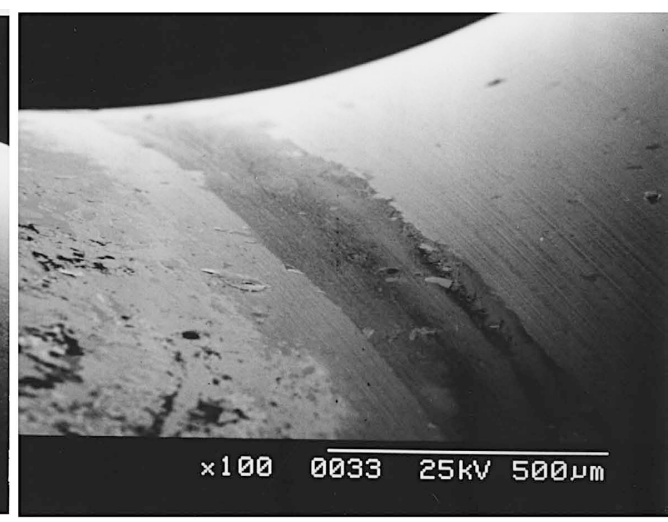

(b)

Fig. 12 SEM images of ball (a) and inner race (b) of the ball bearing after tribo-coating of In.

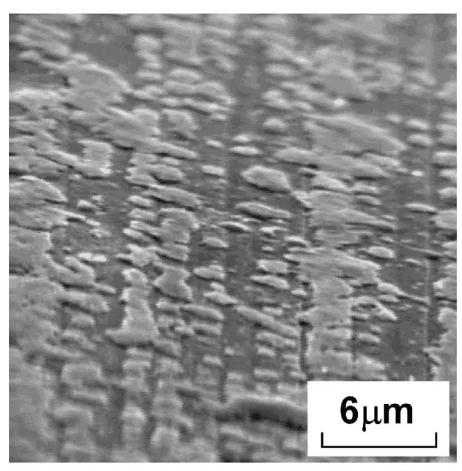

(a) Mode I

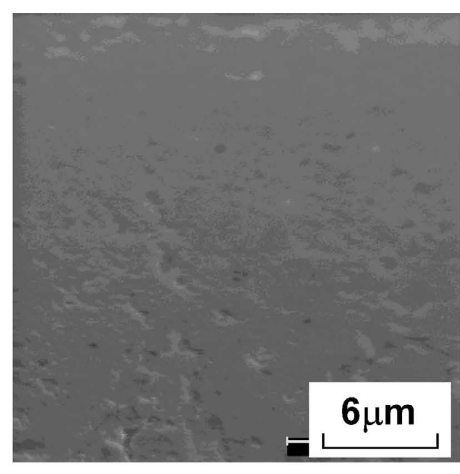

(b) Mode II

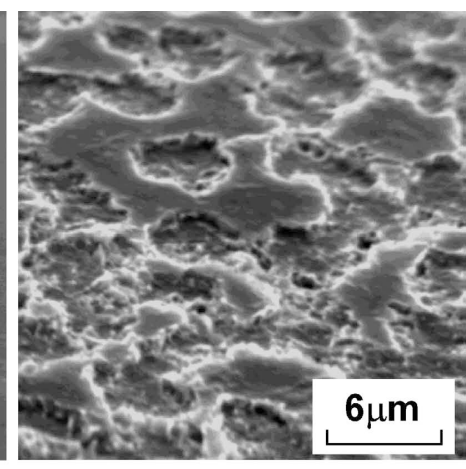

(c) Mode III

Fig. 13 Three representative films observed on the inner ring and outer ring after tribo-coating of In. 
するトライボコーティング膜の形成条件とその形成機構など 解明すべき急務の課題は残されている. しかし，玉軸受にお いて 0.005 以下の摩擦係数を発生し, 必要な時にその摩擦性 能の修復を可能にする「トライボコーティング法」は，高い 信頼性が求められる真空機器用玉軸受にも有効な技術である といえる.

\section{4. 結言}

インジウムのトライボコーティングを施した玉軸受の摩擦 特性に及ぼす軸受構造とトライボコーティング条件の影響を 調査し以下の結論を得た.

（1）最適なスラスト荷重, トライボコーティング供給膜厚, トライボコーティング時の回転速度においてインジウムのト ライボコーティングを施した $\mathrm{Si}_{3} \mathrm{~N}_{4}$ の総玉軸受は, 従来の真 空用玉軸受と同等以下の安定した低い摩擦係数（0.005以下） を与え得ることを実証した。

(2) 再トライボコーティングにより上昇した摩擦を再び減少 させ得ることを示し, トライボコーティング法により真空玉 軸受の 0.005 以下の低摩擦係数の半永久の持続が原理的に可 能であること実証した。

(3) 最適成膜条件でトライボコーティングを施した玉軸受で は, 内外輪に一様なトライボコーティング膜が自己形成さ
れ，これが潤滑膜として機能することを明らかにした。

\section{謝辞}

本研究に際し試験片のご援助をいただきました㧣ジェイテ クトに感謝申し上げます。

\section{[文献}

1) E. W. Roberts: Tribology International, 23 (1990) 95.

2) M. Nishimura and M. Suzuki: Tribology International, 32 (1999) 637.

3) R. N. Bolster, I. L. Singer, J. C. Wegand, S. Fayeulle and C. R. Gosset: Surface and Coatings Technology, 46 (1991) 207.

4) E. W. Roberts: Tribology International, 23 (1990) 95.

5) M. Nishimura and M. Suzuki: Tribology International, 32 (1999) 637.

6) R. A. Rowntree: Tribological Research and Design for Engineering Systems/D. Dowson et al. (Editors), 2003 Elsevier Science B. V., Tribology Series, 41 (2003) 197.

7) K. Kato, H. Furuyama and M. Mizumoto: Proc. of the Japan Int. Trib. Conf., Nagoya, Japan, 1990, (1990) 261.

8) K. Kato, H. Kim, K. Adachi and H. Furuyama: Trans. of the Japan Society of Mechanical Engineers, C, 62 (1996) 3237.

9) K. Adachi and K. Kato: Journal of Japanese Society of Tribologists, 44 (1999) 39.

10) K. Adachi and K. Kato: Shinku, 42 (1999) 804. 